OPEN ACCESS

Edited by:

Wee-Jun Ong,

Xiamen University, Malaysia

Reviewed by:

Lutfi Kurnianditia Putri,

Universiti Sains Malaysia

(USM), Malaysia

Lling-Lling Tan,

Monash University Malaysia, Malaysia

Boon-Junn Ng,

Monash University Malaysia, Malaysia

*Correspondence:

Estelle le Saché

estelle.lesache@surrey.ac.uk

Tomas Ramirez Reina

t.ramirezreina@surrey.ac.uk

Specialty section:

This article was submitted to Catalysis and Photocatalysis,

a section of the journal

Frontiers in Chemistry

Received: 25 February 2021 Accepted: 22 March 2021

Published: 14 April 2021

Citation:

le Saché E, Alvarez Moreno A and Reina TR (2021) Biogas Conversion to Syngas Using Advanced Ni-Promoted

Pyrochlore Catalysts: Effect of the $\mathrm{CH}_{4} / \mathrm{CO}_{2}$ Ratio

Front. Chem. 9:672419.

doi: 10.3389/fchem.2021.672419

\section{Biogas Conversion to Syngas Using Advanced Ni-Promoted Pyrochlore Catalysts: Effect of the $\mathrm{CH}_{4} / \mathrm{CO}_{2}$ Ratio}

\author{
Estelle le Saché $^{1 *}$, Andrea Alvarez Moreno ${ }^{2}$ and Tomas Ramirez Reina ${ }^{1,3 *}$ \\ ${ }^{1}$ Department of Chemical and Process Engineering, University of Surrey, Guildford, United Kingdom, ${ }^{2}$ Estado Sólido y \\ Catálisis Ambiental, Departamento de Química, Facultad de Ciencias, Universidad Nacional de Colombia, Bogotá, Colombia, \\ ${ }^{3}$ Inorganic Chemistry Department, Material Science Institute, University of Seville-CSIC, Seville, Spain
}

Biogas is defined as the mixture of $\mathrm{CH}_{4}$ and $\mathrm{CO}_{2}$ produced by the anaerobic digestion of biomass. This particular mixture can be transformed in high valuable intermediates such as syngas through a process known as dry reforming (DRM). The reaction involved is highly endothermic, and catalysts capable to endure carbon deposition and metal particle sintering are required. Ni-pyrochlore catalysts have shown outstanding results in the DRM. However, most reported data deals with $\mathrm{CH}_{4} / \mathrm{CO}_{2}$ stoichiometric ratios resulting is a very narrow picture of the overall biogas upgrading via DRM. Therefore, this study explores the performance of an optimized Ni-doped pyrochlore, and Ni-impregnated pyrochlore catalysts in the dry reforming of methane, under different $\mathrm{CH}_{4} / \mathrm{CO}_{2}$ ratios, in order to simulate various representatives waste biomass feedstocks. Long-term stability tests showed that the ratio $\mathrm{CH}_{4} / \mathrm{CO}_{2}$ in the feed gas stream has an important influence in the catalysts' deactivation. Ni doped pyrochlore catalyst, presents less deactivation than the $\mathrm{Ni}$-impregnated pyrochlore. However, biogas mixtures with a $\mathrm{CH}_{4}$ content higher than $60 \%$, lead to a stronger deactivation in both $\mathrm{Ni}$-catalysts. These results were in agreement with the thermogravimetric analysis (TGA) of the post reacted samples that showed a very limited carbon formation when using biogas mixtures with $\mathrm{CH}_{4}$ content $<60 \%$, but $\mathrm{CH}_{4} / \mathrm{CO}_{2}$ ratios higher than 1.25 lead to an evident carbon deposition. TGA analysis of the post reacted $\mathrm{Ni}$ impregnated pyrochlore, showed the highest amount of carbon deposited, even with lower stoichiometric $\mathrm{CH}_{4} / \mathrm{CO}_{2}$ ratios. The later result indicates that stabilization of $\mathrm{Ni}$ in the pyrochlore structure is vital, in order to enhance the coke resistance of this type of catalysts.

Keywords: biogas, dry reforming, $\mathrm{Ni}$ catalysts, $\mathrm{CH}_{4} / \mathrm{CO}_{2}$ ratio, bioenergy

\section{INTRODUCTION}

In the continuous search of renewable energy sources, the world has turned again toward the use of biomass. Biomass represents an alternative to fossil fuels and could be as versatile through several conversion processes including combustion, pyrolysis, fermentation, gasification, and anaerobic digestion (Papadopoulou et al., 2012). 
TABLE 1 | Biogas from different feedstocks.

\begin{tabular}{lccc}
\hline Biogas source & $\mathbf{C H}_{\mathbf{4}}(\%)$ & $\mathbf{C O}_{\mathbf{2}}(\%)$ & $\mathbf{N}_{\mathbf{2}}(\%)$ \\
\hline Landfill Waste & $45-62$ & $24-40$ & $1-17$ \\
Sewage Waste & $58-65$ & $33-40$ & $1-8$ \\
Organic Waste & $60-70$ & $30-40$ & $1-5$ \\
\hline
\end{tabular}

Data obtained from Papadopoulou et al. (2012) and Ullah Khan et al. (2017).

While the combustion of biomass allows the production of heat and electricity, pyrolysis, and fermentation processes allow the production of liquid fuels suitable for combustion engines or liquid energy carriers. Thermal biomass gasification produces a gas mixture composed of $\mathrm{H}_{2}, \mathrm{CO}, \mathrm{CH}_{4}, \mathrm{CO}_{2}, \mathrm{H}_{2} \mathrm{O}, \mathrm{N}_{2}$, and light hydrocarbons. However, this process is energy intensive due to the high moisture content of biomass, and require critical process demands due to the large production of tar (Neubauer, 2013; Ren et al., 2020). Anaerobic digestion on the other hand, is based on the decomposition of organic matter in the absence of $\mathrm{O}_{2}$ by bacterial action and requires much less energy than gasification or combustion. Through this process, several types of biomass can be converted into a gas mixture of methane $\left(\mathrm{CH}_{4}\right)$ and carbon dioxide $\left(\mathrm{CO}_{2}\right)$, known as biogas (Wu et al., 2019).

This particular gas mixture can be considered quite contaminant, since both molecules are well-recognized greenhouse gases, however, when coupling this mixture with the $\mathrm{CO}_{2}$ reforming process (also known as dry reforming), high valuable intermediates such as synthesis gas (syngas) can be generated (equation 1).

$$
\mathrm{CH}_{4}+\mathrm{CO}_{2} \leftrightarrows 2 \mathrm{H}_{2}+2 \mathrm{CO} \quad \Delta \mathrm{H}_{298}=+247 \mathrm{~kJ} \mathrm{~mol}^{-1}
$$

Syngas is known to be a primary feedstock to synthesize fuels and chemicals such as methanol, DME, as well as longchained hydrocarbons via the Fischer-Tropsch process (Santos and Alencar, 2020; Zhao et al., 2020). Additionally, it has been suggested as a feed gas to high temperature solid oxide fuel cells (SOFCs) for electricity generation (Lanzini and Leone, 2010; Shiratori et al., 2010).

$\mathrm{CO}_{2}$ reforming has been reported as one of the main strategies in the carbon capture and utilization (CCU) approach. Still, from a $\mathrm{CO}_{2}$ emissions mitigation perspective, dry reforming (DRM) has a limited impact considering the high energy input required to reach operating conditions. However, when coupling DRM with biomass utilization, its environmental advantage is incredibly boosted.

Municipal waste, sewage sludge, animal manure, and agricultural waste are widely known to be the characteristic feedstocks for biogas production. Nevertheless, the biogas composition may vary upon the biodegradable source since it is dependent on the composition, density and water content of the source. While landfill waste can generate a biogas with a $\mathrm{CH}_{4}$ content around $40 \%$ and a $\mathrm{CO}_{2}$ content around $40 \%$, agricultural waste can generate a biogas containing $70 \%$ of $\mathrm{CH}_{4}$, and a $30 \%$ of $\mathrm{CO}_{2}$. Representative feedstocks and their corresponding biogas compositions are listed in Table $\mathbf{1 .}$
Syngas generation through dry reforming of biogas is usually performed with metal-based catalysts. However, some critical characteristics are required in these solids. To begin with, they need to be able to activate both molecules $\left(\mathrm{CH}_{4}\right.$ and $\mathrm{CO}_{2}$ ). Then, a strong resistance toward coke deposition is required, as the reaction is extremely endothermic and methane decomposition is favored on the same temperature range. Lastly, they must be stable in order to avoid sintering of the metal particles and subsequent loss of active surface. Noble metal catalysts (based in $\mathrm{Rh}, \mathrm{Ru}, \mathrm{Pd}$ ) fulfill all of these requirements (Abdulrasheed et al., 2019; Aziz et al., 2019), however, for large-scale applications, low-cost transition metals are preferred. Among them, Ni-based catalysts standout. They are much cheaper and have comparable catalytic activities with noble metals. Nevertheless, coke deposition and sintering of $\mathrm{Ni}$ particles, are their most important drawbacks. In order to overcome this challenge, strategies regarding the stabilization of $\mathrm{Ni}$, have been proposed. The use of supports such as fluorites, hexaaluminates, perovskites, and pyrochlores, has been investigated for this purpose (Dama et al., 2018; le Saché et al., 2018, 2020).

Pyrochlores are a very interesting family of materials. Generally speaking, they are defined as mixed oxides with the general formula $\mathrm{A}_{2} \mathrm{~B}_{2} \mathrm{O}_{7}$. " $\mathrm{A}$ " represents a large trivalent cation, typically a rare-earth metal such as $\mathrm{La}$, and " $\mathrm{B}$ " represents a tetravalent cation of smaller diameter, typically a transition metal such as Zr (Shukla et al., 2015). Pyrochlores present a high thermal stability and high oxygen mobility which makes them excellent candidates for high temperature and coke resistance operations (Zhang et al., 2017). Previous work in our group showed that the substitution of $10 \mathrm{wt} . \% \mathrm{Ni}$ on the $\mathrm{B}$ site of a $\mathrm{La}_{2} \mathrm{Zr}_{2} \mathrm{O}_{7}$ pyrochlore led to a very active, stable, and carbon resistant catalyst for dry reforming of methane (DRM) (le Saché et al., 2018; Reina et al., 2020). Likewise, the Ni impregnated pyrochlore structure has also been reported as active in the DRM (le Saché et al., 2020). However, these catalysts have only been tested under $\mathrm{CH}_{4} / \mathrm{CO}_{2}$ stoichiometric ratios. Therefore, this work studies the performance of the optimized Ni-doped pyrochlore, and compares it with $\mathrm{Ni}$-impregnated pyrochlore catalysts in the DRM under different $\mathrm{CH}_{4} / \mathrm{CO}_{2}$ ratios, in order to simulate different waste biomass feedstocks. The work aims to showcase suitable upgrading routes for different types of biogas by the $\mathrm{CO}_{2}$ reforming process.

\section{MATERIALS AND METHODS}

\section{Catalyst Preparation}

The $10 \%$ Ni-doped pyrochlore was synthesized using a modified citrate method described elsewhere (le Saché et al., 2018, 2020; Reina et al., 2020). In summary, lanthanum nitrate $\left[\mathrm{La}\left(\mathrm{NO}_{3}\right)_{3} \cdot 6 \mathrm{H}_{2} \mathrm{O}\right]$, nickel nitrate $\left[\mathrm{Ni}\left(\mathrm{NO}_{3}\right)_{2} \cdot 6 \mathrm{H}_{2} \mathrm{O}\right]$, and zirconyl nitrate $\left[\mathrm{ZrO}\left(\mathrm{NO}_{3}\right)_{2} \cdot 6 \mathrm{H}_{2} \mathrm{O}\right]$ were used as precursors. Salts were dissolved in deionized, and then mixed with a citric acid solution. The required amount of each precursor was adjusted to reach a Ni loading of $10 \mathrm{wt} . \%$. The solution was concentrated in a rotary evaporator and then dried for $12 \mathrm{~h}$ at $100^{\circ} \mathrm{C}$ to then be combusted at $200^{\circ} \mathrm{C}$. Finally, all solids were 
TABLE 2 | Biogas mixtures used in the catalytic testing.

\begin{tabular}{lccc}
\hline Biogas mixture & $\mathbf{C H}_{\mathbf{4}} \mathbf{( \% )}$ & $\mathbf{C O}_{\mathbf{2}} \mathbf{( \% )}$ & $\mathbf{C H}_{\mathbf{4}} / \mathbf{C O}_{\mathbf{2}}$ molar ratio \\
\hline Stoichiometric mixture & 50 & 50 & 1 \\
1 & 55 & 45 & 1.25 \\
2 & 60 & 40 & 1.5 \\
3 & 65 & 35 & 1.85 \\
\hline
\end{tabular}

calcined at $1,000^{\circ} \mathrm{C}$ for $8 \mathrm{~h}$. Ni-doped pyrochlore will be referred as LNZ10.

A second catalyst was prepared by the wet impregnation of $\mathrm{Ni}$ on the un-doped pyrochlore. The $\mathrm{La}_{2} \mathrm{Zr}_{2} \mathrm{O}_{7}$ support was prepared by the same citrate method. Ni was then impregnated to reach a Ni loading of $10 \mathrm{wt} . \%$. A $1 \mathrm{M}$ solution of $\mathrm{Ni}\left(\mathrm{NO}_{3}\right)_{2} \cdot 6 \mathrm{H}_{2} \mathrm{O}$ (Sigma Aldrich, 99.999\%) in ethanol was added to the support and stirred for $2 \mathrm{~h}$. The solvent was removed in a rotary evaporator and the resulting powder was dried for $12 \mathrm{~h}$ at $100^{\circ} \mathrm{C}$ before calcination at $500^{\circ} \mathrm{C}$ for $4 \mathrm{~h}$. The impregnated catalyst will be referred as $\mathrm{Ni} / \mathrm{LZ}$.

\section{Thermodynamic Analysis}

The thermodynamic equilibrium calculations over a range of temperatures, was performed by the Gibbs free energy minimization method using the ChemCad 6.5.5 software. Soave-Redlich-Kwong equation of state was used for fugacity calculations due to its large range applicability in terms of temperature (Perry et al., 1997).

\section{Catalytic Behavior}

The reforming of various biogas mixtures was performed in a down flow fixed bed tubular quartz reactor placed in a tubular furnace. The temperature of the catalytic bed is monitored by a K-type thermocouple and recorded using PicoLog 5 software. The gaseous reactants are mixed in a mixing chamber and fed into the reactor by mass flow controllers from Aalborg. The gas stream may be redirected to a bubble flow meter by means of a 3-valve. At the reactor outlet, the product stream passes through two coalescence filters from Headline Filters to separate any liquid product. The remaining gas flow is then sent to an online gas chromatograph HP 6890 from Agilent equipped with a Carboxen-1000 packed column and a TCD detector.

The reforming of biogas was performed on $100 \mathrm{mg}$ of catalyst at a WHSV of $30 \mathrm{~L} \mathrm{~g}^{-1} \mathrm{~h}^{-1}$. Prior to reaction, the catalyst was reduced for $1 \mathrm{~h}$ at $700^{\circ} \mathrm{C}$ in 10 vol. $\% \mathrm{H}_{2} / \mathrm{N}_{2}$. Temperature screening experiments were performed for temperatures ranging from 550 to $850^{\circ} \mathrm{C}$ in $50^{\circ} \mathrm{C}$ increments of $45 \mathrm{~min}$. Time dependent experiments were performed at $700^{\circ} \mathrm{C}$ for $24 \mathrm{~h}$. The catalytic performance was measured for $\mathrm{CH}_{4} / \mathrm{CO}_{2}$ molar ratios of $1,1.25,1.5$, and 1.85 balanced in $\mathrm{N}_{2}$ in order to model biogas mixtures produced from a range of residues (Table 2).

\section{Catalysts Characterization}

\section{$\mathrm{CH}_{4}$-Temperature-Programmed Surface Reaction}

$\mathrm{CH}_{4}$-TPSR took place in a locally built fixed bed quartz reactor coupled with a Pfeiffer Vacuum OmniStar GSD 320 mass spectrometer. The experiment was performed on the catalysts reduced in-situ at $700^{\circ} \mathrm{C}$ for $1 \mathrm{~h}$. The temperature was risen to $900^{\circ} \mathrm{C}$ at a heating rate of $10^{\circ} \mathrm{C} \mathrm{min}^{-1}$ and maintained for $30 \mathrm{~min}$. A flow of $10 \mathrm{vol} \% \mathrm{CH}_{4} / \mathrm{Ar}$ was passed through the reactor and mass to charge ratio $(\mathrm{m} / \mathrm{z})$ of $2,15,18,28$, and 44 corresponding to $\mathrm{H}_{2}, \mathrm{CH}_{4}, \mathrm{H}_{2} \mathrm{O}, \mathrm{CO}$, and $\mathrm{CO}_{2}$, respectively, were recorded.

\section{X-Ray Powder Diffraction}

XRD analysis was undertaken using a PANalytical X'Pert Powder. The samples were analyzed after calcination, reduction and after reaction. The diffraction patterns were recorded with $\mathrm{Cu} \mathrm{K} \alpha$ $(30 \mathrm{~mA}, 40 \mathrm{kV})$ over a $2 \theta$ range of $10-90^{\circ}$, using a position sensitive detector with a step size of $0.05^{\circ}$ and a step time of $450 \mathrm{~s}$. The powder XRD patterns were further processed using the software X’PertHighscore Plus@.

\section{Transmission Electron Microscopy}

TEM images were taken with a JEOL electron microscope (model JEM-2010) working at $200 \mathrm{kV}$. It was equipped with an INCA Energy TEM 100 analytical system and a SIS MegaView II camera. Samples for analysis were suspended in ethanol and placed on copper grids with a holey-carbon film support.

\section{Thermogravimetric Analysis}

TGA was performed on the spent catalysts in an SDT Q600 V8.3 from TA Instruments. The sample was ramped from room temperature to $900^{\circ} \mathrm{C}$ at a rate of $10^{\circ} \mathrm{C} \mathrm{min}{ }^{-1}$. Experiments were conducted in $100 \mathrm{~mL} \mathrm{~min}^{-1}$ of Air.

\section{RESULTS AND DISCUSSION}

\section{Thermodynamic Analysis}

Figure 1, simulates the DRM reaction under the different $\mathrm{CH}_{4} / \mathrm{CO}_{2}$ ratios described in Table 2. In each graph two sections can be evidenced. First, from 0 to $500^{\circ} \mathrm{C}$ a higher concentration of carbon and water is observed, with the presence of the main reactants $\mathrm{CH}_{4}$ and $\mathrm{CO}_{2}$. Secondly, from $500^{\circ} \mathrm{C}$ onwards the concentrations of $\mathrm{CH}_{4}$ and $\mathrm{CO}_{2}$ gradually decrease as $\mathrm{H}_{2}$ and $\mathrm{CO}$ production is evidenced, accompanied with carbon formation.

The low temperature zone is dominated by the Boudouard reaction (equation 2) and the reverse gasification of carbon (equation 3) (Zheng et al., 2017).

$$
\begin{aligned}
2 \mathrm{CO} \leftrightarrows \mathrm{C}+\mathrm{CO}_{2} & \Delta \mathrm{H}_{298}=-172 \mathrm{~kJ} \mathrm{~mol}^{-1} \\
\mathrm{CO}+\mathrm{H}_{2} \leftrightarrows \mathrm{C}+\mathrm{H}_{2} \mathrm{O} & \Delta \mathrm{H}_{298}=-131 \mathrm{~kJ} \mathrm{~mol}^{-1}
\end{aligned}
$$

The presence of $\mathrm{CO}$ and water is owed to the reverse water gas shift (RGWS) (equation 4) that is present in a very wide range of temperatures (Chein et al., 2015).

$$
\mathrm{CO}_{2}+\mathrm{H}_{2} \leftrightarrows \mathrm{CO}+\mathrm{H}_{2} \mathrm{O} \quad \Delta \mathrm{H}_{298}=41.4 \mathrm{~kJ} \mathrm{~mol}^{-1}
$$

On the other hand, the high temperature area of the graph is characterized by the DRM reaction (equation 1), which agrees with the low $\mathrm{CH}_{4}$ and $\mathrm{CO}_{2}$ concentration, while $\mathrm{H}_{2}$ and $\mathrm{CO}$ are the primary products. The carbon present, is mainly owed to the 

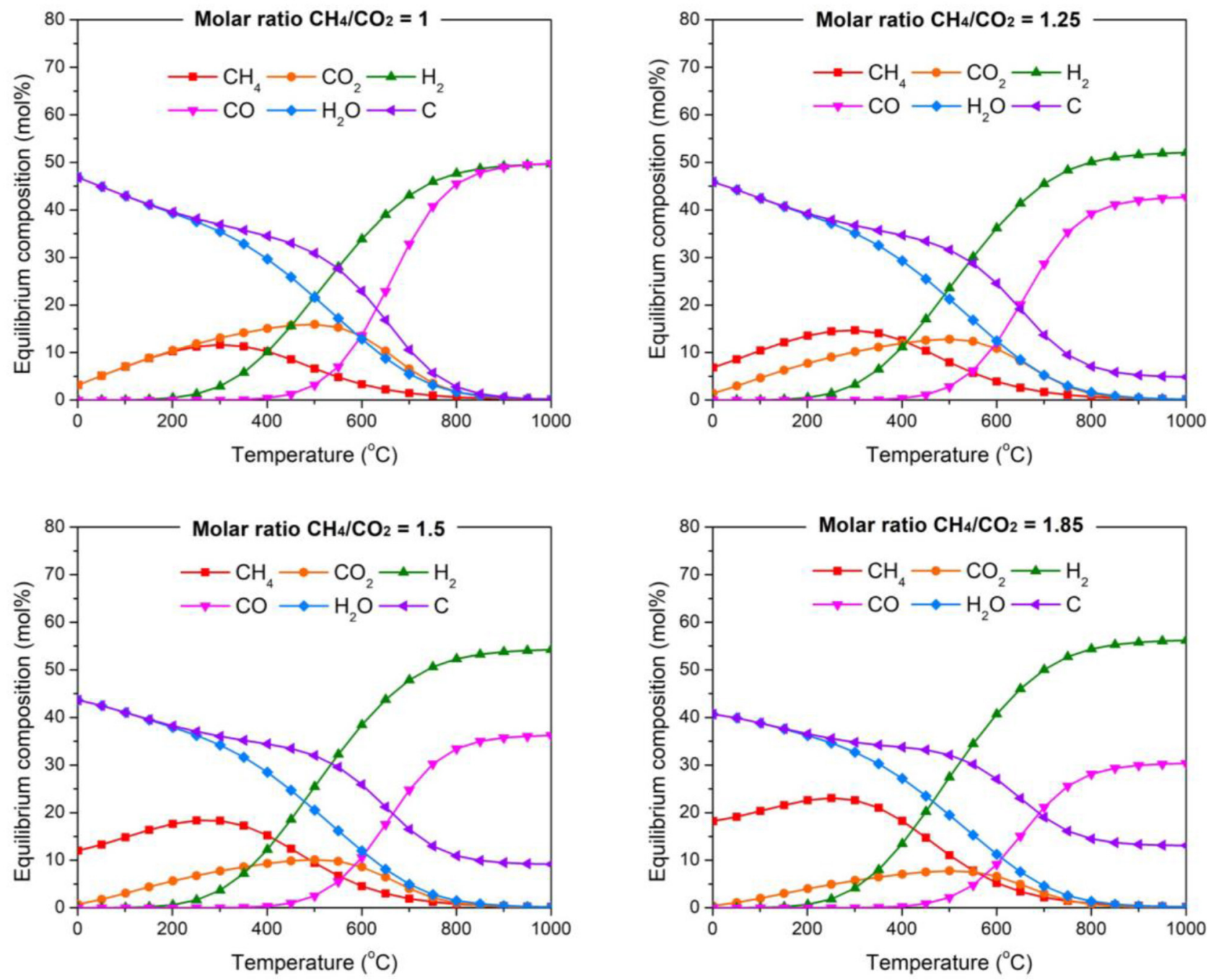

FIGURE 1 | Thermodynamic equilibrium plots of DRM under different biogas mixtures at 1 bar using ChemCad 6.5.5 software.
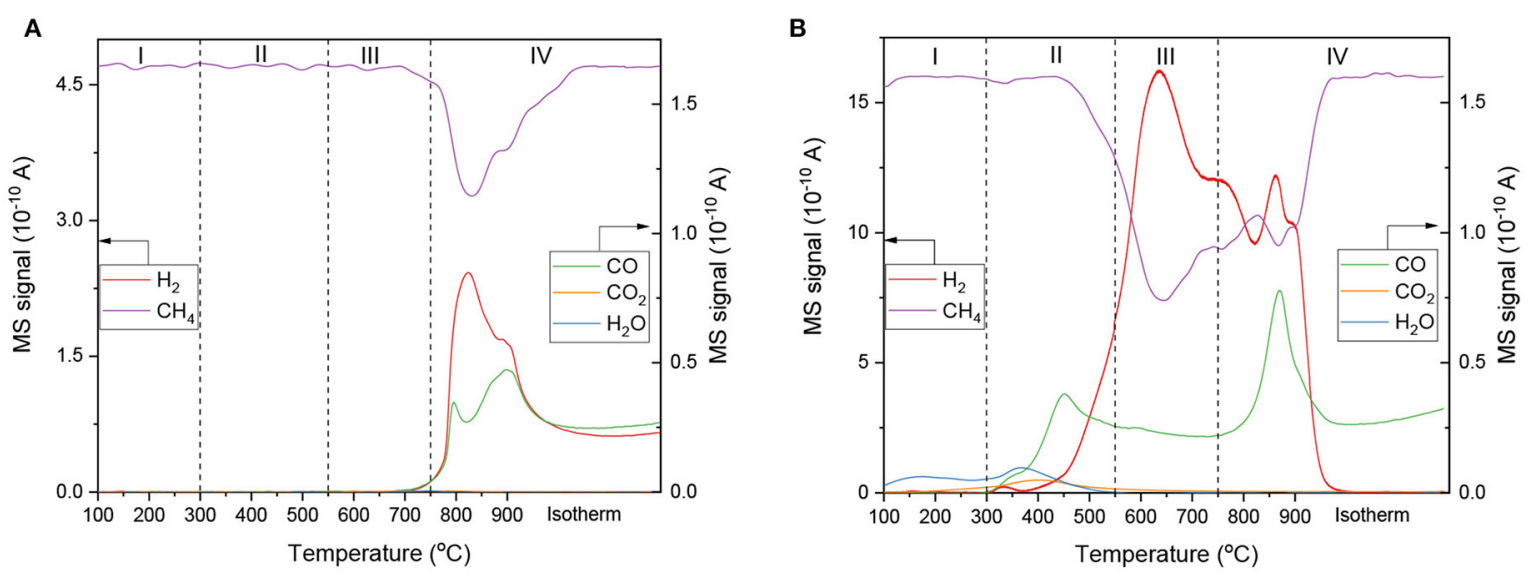

FIGURE 2 | $\mathrm{CH}_{4}$-TPSR profiles of (A) $L Z$, and (B) LNZ10. 

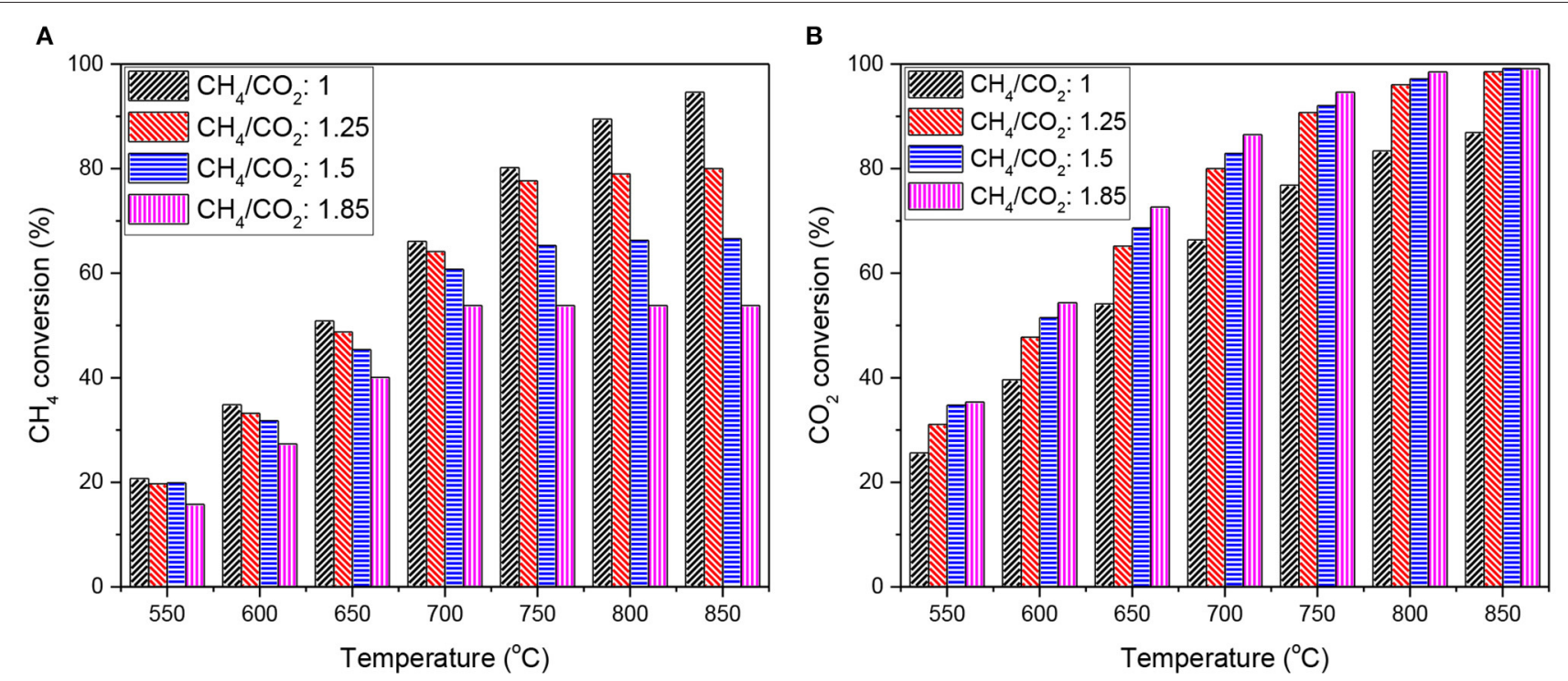

C

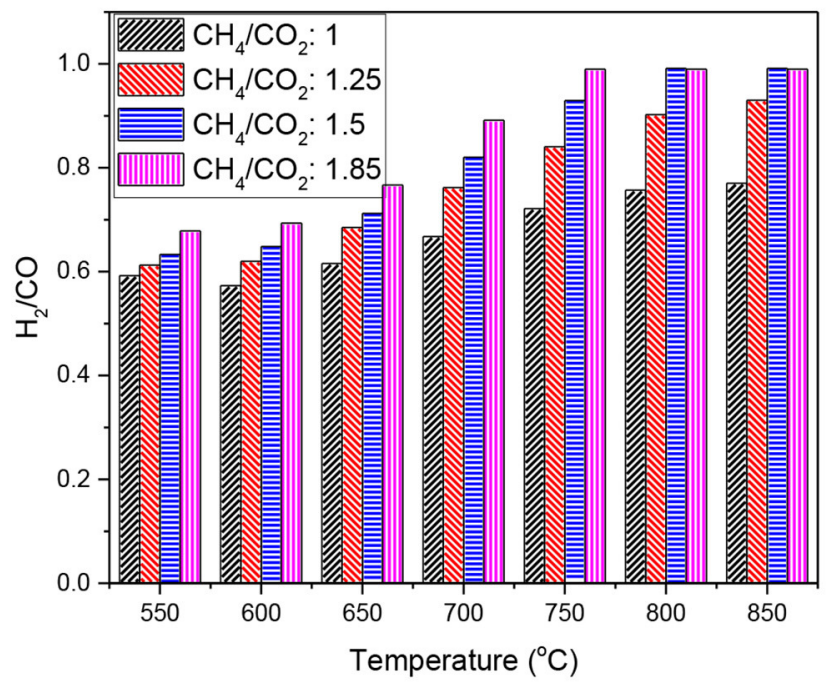

FIGURE 3 | Temperature dependent reaction using different biogas feedstock on $\mathrm{LNZ10}$ (A) $\mathrm{CH}_{4}$ conversion and (B) $\mathrm{CO}_{2} \mathrm{Conversion}_{\mathbf{( C )}} \mathrm{H}_{2} / \mathrm{CO}$ ratio.

decomposition of methane (equation 5) that is favored at high temperatures (Zhang et al., 2007).

$$
\mathrm{CH}_{4} \leftrightarrows \mathrm{C}+2 \mathrm{H}_{2} \quad \Delta \mathrm{H}_{298}=75 \mathrm{~kJ} \mathrm{~mol}^{-1}
$$

Since the consumption of $\mathrm{CO}_{2}$ occurs at temperatures higher than $500^{\circ} \mathrm{C}$, the $550-850^{\circ} \mathrm{C}$ temperature range was selected for the catalytic tests, where carbon deposition is likely to occur. Regarding the different $\mathrm{CH}_{4} / \mathrm{CO}_{2}$ ratios, it is clearly evidenced that the amount of $\mathrm{H}_{2}$ and $\mathrm{C}$ in the stream increases with $\mathrm{CH}_{4} / \mathrm{CO}_{2}$ ratio, owing mainly to the excess methane at the inlet stream. In this way, the present simulation also provides information about the syngas composition that could be produced if DRM was performed with various $\mathrm{CH}_{4} / \mathrm{CO}_{2}$ ratios. Increasing the
$\mathrm{CH}_{4} / \mathrm{CO}_{2}$ ratio, the $\mathrm{H}_{2}$ content can reach up to $55 \%$ and the $\mathrm{CO}$ content, $35 \%$. This imply that the $\mathrm{H}_{2} / \mathrm{CO}$ ratio could be $>1$, suggesting that biogas reforming could produce syngas suitable for a wider range of products through the Fischer-Tropsch process.

\section{$\mathrm{CH}_{4}$-Temperature-Programmed Surface Reaction}

The contribution of the pyrochlore and $\mathrm{Ni}$ to activate methane was studied by means of $\mathrm{CH}_{4}$-TPSR. In this experiment, solely $\mathrm{CH}_{4}$ is introduced in the reactor, which can also be used to monitor the participation of active lattice oxygen during reaction. The absence of $\mathrm{O}_{2}$ or $\mathrm{CO}_{2}$ in the feed, allows to study the lattice oxygen conductivity in the pyrochlore through 

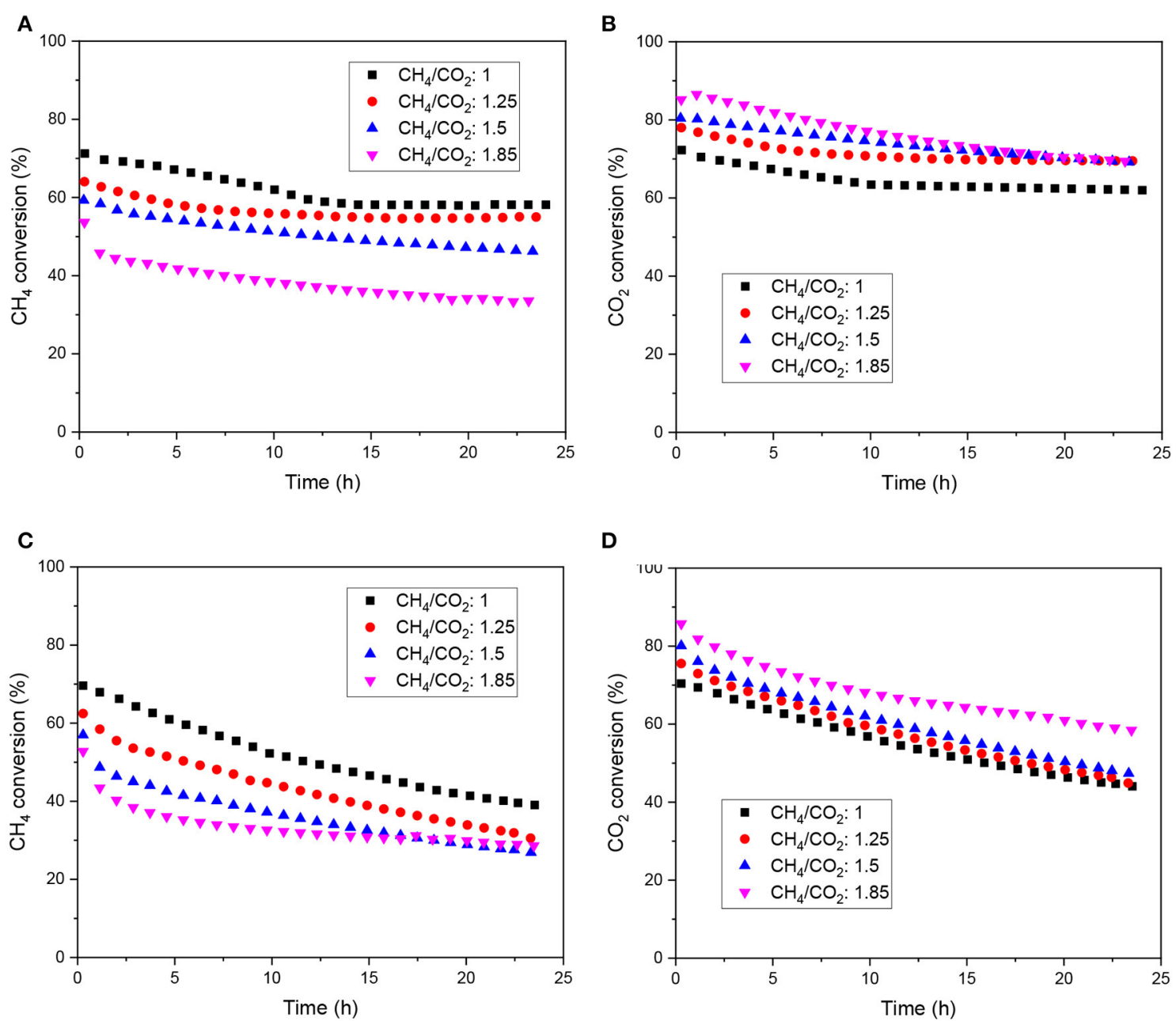

D

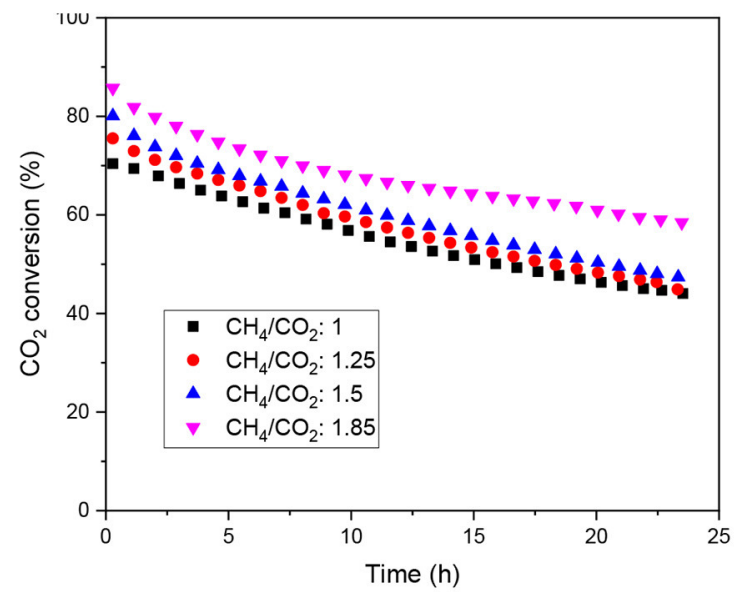

FIGURE 4 | Stability test using different biogas feedstock on LNZ10 (A) $\mathrm{CH}_{4}$ conversion, (B) $\mathrm{CO}_{2}$ conversion and on Ni/LZ (C) $\mathrm{CH}_{4}$ conversion, (D) $\mathrm{CO} 2$ conversion.

the formation of $\mathrm{CO}$ or $\mathrm{CO}_{2}$ (Pakhare et al., 2012). The support $\mathrm{La}_{2} \mathrm{Zr}_{2} \mathrm{O}_{7}$ pyrochlore (LZ) was compared to the doped sample LNZ10. The desorption profiles of the reagent and products arising from the reaction are shown in Figure 2. Four temperature regions can be distinguished, corresponding to different dissociation processes. At temperatures lower than $300^{\circ} \mathrm{C}$, no dissociation occurs. In the $300-550^{\circ} \mathrm{C}$ temperature range, a minor methane consumption is detected in the $\mathrm{Ni}$ containing catalyst. This process is accompanied by the production of water, carbon monoxide, carbon dioxide, and hydrogen, indicating some methane decomposition on $\mathrm{Ni}$ active sites, and methane combustion with adsorbed surface oxygen, following Equation (6) (Khajonvittayakul et al., 2019). Methane combustion was not detected on the bare pyrochlore indicating the lack of easily accessible surface oxygen. On the other hand, this reaction occurred on LNZ10, indicating the higher accessibility of surface oxygen in the doped catalysts. The production of $\mathrm{CO}$ at $c a .450^{\circ} \mathrm{C}$ could also be due to the reaction of oxygen associated with $\mathrm{Ni}$ in the pyrochlore/perovskite structure as suggested by Pakhare et al. with doped pyrochlores (Pakhare et al., 2012).

$$
\mathrm{CH}_{4}+4 \mathrm{O}^{*} \rightarrow \mathrm{CO}_{2}+2 \mathrm{H}_{2} \mathrm{O}
$$

The activation mechanism occurring between 550 and $750^{\circ} \mathrm{C}$ is referred as region III in Figure 2. Here, a rapid hydrogen production is witnessed, along a major methane consumption on the Ni doped sample. The limited $\mathrm{CO}$ production suggests that this process is mainly due to $\mathrm{CH}_{4}$ dissociation on $\mathrm{Ni}$ active sites according to Equation (7). This indicates that to avoid carbon deposition, $\mathrm{CO}_{2}$ must be readily activated at temperature as low as $500^{\circ} \mathrm{C}$.

$$
\mathrm{CH}_{4}+\mathrm{Ni} \rightarrow \mathrm{Ni}-\mathrm{C}+2 \mathrm{H}_{2}
$$

Lastly, in region IV, at temperatures above $750^{\circ} \mathrm{C}$, a final $\mathrm{CH}_{4}$ consumption occurs, forming larger amount of $\mathrm{CO}$. This process is observed for both samples, including the bare $\mathrm{La}_{2} \mathrm{Zr}_{2} \mathrm{O}_{7}$ 

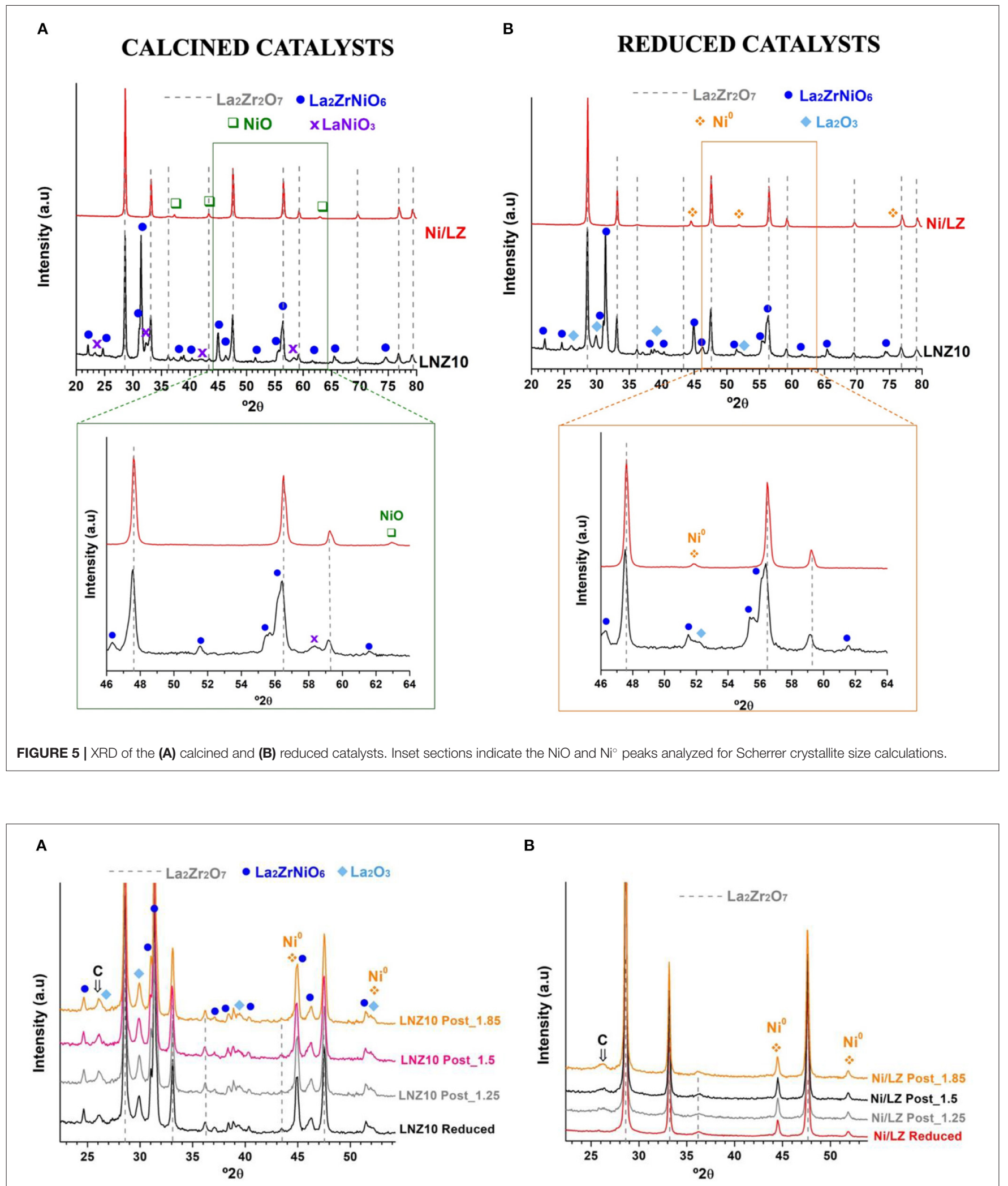

FIGURE 6 | XRD of the post reacted samples under $\mathrm{CH}_{4} / \mathrm{CO}_{2}$ ratios higher than 1. (A) Doped sample and (B) supported sample. 
pyrochlore, implying that oxygen from the pyrochlore lattice is able to dissociate methane at high temperature, following (equation 8) (Zheng et al., 2017).

$$
\mathrm{CH}_{4}+\mathrm{O}^{*} \rightarrow \mathrm{CO}+2 \mathrm{H}_{2}
$$

Additionally, on the Ni containing catalyst, the coked $\mathrm{Ni}$ - $\mathrm{C}$ sites resulting from Equation (7) can supposedly further react with lattice oxygen to form $\mathrm{CO}$, regenerating $\mathrm{Ni}-\mathrm{C}$ to its original active form $\mathrm{Ni}$. Although methane could still potentially dissociate on $\mathrm{Ni}$ - $\mathrm{C}$ sites, leading to the formation of filaments of carbon, the complete decline of $\mathrm{H}_{2}$ production during the high temperature isotherm suggests otherwise.

Overall the doped catalyst was able to dissociate methane at temperatures as low as $400^{\circ} \mathrm{C}$, which sets them as good candidates for low temperature dry reforming. Additionally, the pyrochlore structure was found to have a good oxygen storage capacity, with some surface oxygen and active lattice oxygen.

\section{Catalytic Behavior Temperature Effect}

Dry reforming of various biogas mixtures was performed on the doped catalyst, LNZ10. The effect of temperature on $\mathrm{CH}_{4}$ and $\mathrm{CO}_{2}$ conversions, besides the $\mathrm{H}_{2} / \mathrm{CO}$ ratio obtained, is represented in Figure 3. The catalyst achieved high conversions at relatively low temperatures. Thermodynamic equilibrium conversions were reached at temperature above $700^{\circ} \mathrm{C}$. The conversion of methane decreased upon increasing methane content. In particular, methane conversion is limited at high temperature as suggested by thermodynamic calculations. $\mathrm{CO}_{2}$ conversions on the other hand, are very similar between biogas feedstock. For $\mathrm{CH}_{4} / \mathrm{CO}_{2}$ superior to $1, \mathrm{CO}_{2}$ is the limiting reactant resulting in high conversions. Additionally, the $\mathrm{H}_{2} / \mathrm{CO}$ ratio produced increases with methane concentration in the feed stream as suggested thermodynamically.

\section{Time Dependent Performance}

Long-term stability tests were carried out at $700^{\circ} \mathrm{C}$ on the doped and supported catalysts, where carbon deposition is favored for each ratio according to Figure 1. $\mathrm{CH}_{4}$ and $\mathrm{CO}_{2}$ conversion as a function of time are displayed in Figure 4 for various biogas feedstocks. The doped catalyst (LNZ10)

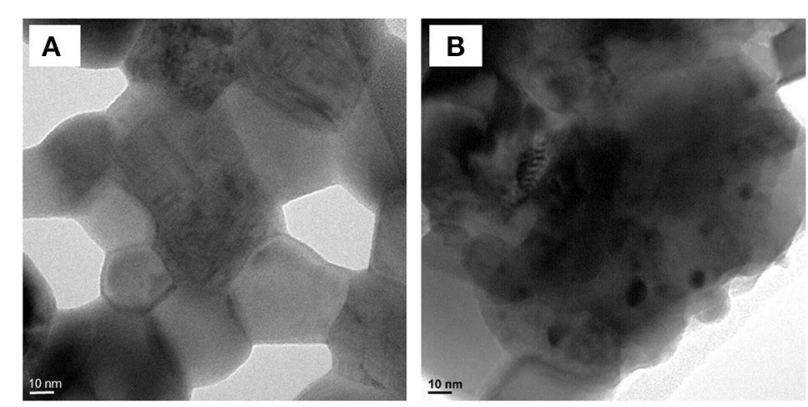

FIGURE 7 | TEM of the doped sample (A) calcined and (B) post stability test under $\mathrm{CH}_{4} / \mathrm{CO}_{2}: 1$. displayed relatively stable activity for biogas mixtures with relatively low methane content $\left(\mathrm{CH}_{4} / \mathrm{CO}_{2}=1\right.$ and 1.25), however, a small deactivation was observed when using higher $\mathrm{CH}_{4} / \mathrm{CO}_{2}$ ratios. In particular, a deactivation of about $25 \%$ in conversion was observed when the reaction was performed under a biogas mixture of $\mathrm{CH}_{4} / \mathrm{CO}_{2}=1.85$, where carbon deposition is favored, owed to the excess of methane in the inlet stream.

On the other hand, the supported catalyst showed continuous deactivation for all the range of biogas feedstocks. A deactivation of about $30 \%$ in conversion was observed for the lowest methane containing biogas.

The different catalytic behavior of both samples can be explained by the different $\mathrm{Ni}$ species in both catalysts. For one side, the calcined doped sample (LNZ10) presents the characteristic diffraction peaks of the $\mathrm{La}_{2} \mathrm{Zr}_{2} \mathrm{O}_{7}$ pyrochlore phase and the $\mathrm{La}_{2} \mathrm{NiZrO}_{6}$ rhombohedral double perovskite oxide phase (Figure 5) (le Saché et al., 2018, 2020). The presence of the latter, implies that the $\mathrm{Ni} \%$ utilized in the synthesis method, surpassed the maximum substitution limit of the pyrochlore structure leading to the formation of this additional phase (Haynes et al., 2017). $\mathrm{Zr}$ and $\mathrm{La}$ seemed to be fully incorporated into the pyrochlore and/or the perovskite oxide phase, since no $\mathrm{ZrO}_{2}$ or $\mathrm{La}_{2} \mathrm{O}_{3}$ oxides are observed, however, traces of $\mathrm{LaNiO}_{3}$ are detected at $32.3^{\circ} 2 \theta$ in the calcined sample. Likewise, $\mathrm{Ni}$ seems to be fully incorporated into the mixed structures as no $\mathrm{NiO}$ is observed.

Regarding the calcined impregnated sample (Ni/LZ) diffraction peaks of $\mathrm{NiO}$ additionally to the $\mathrm{La}_{2} \mathrm{Zr}_{2} \mathrm{O}_{7}$ pyrochlore phase are evidenced. In this catalysts, the rhombohedral double perovskite oxide phase $\left(\mathrm{La}_{2} \mathrm{NiZrO}_{6}\right)$ was not formed owed to the calcination process. In this sample, $\mathrm{NiO}$ crystallite size calculated by Scherrer Equation using the peak at $62,8^{\circ} 2 \theta$ was: $24 \mathrm{~nm}$. When reduced, the impregnated sample displays the same XRD pattern, however, metallic $\mathrm{Ni}^{0}$ is evidenced at 44,5 and $51,8^{\circ} 2 \theta$. The doped sample on the other hand, shows traces of $\mathrm{La}_{2} \mathrm{O}_{3}$ in addition to $\mathrm{Ni}^{0}$, resulting from the reduction of $\mathrm{LaNiO}_{3}$. In the reduced samples, no difference in the $\mathrm{Ni}^{0}$ crystallite size is evidenced. $\mathrm{Ni}^{0}$ crystallite size calculated by Scherrer Equation with the $44,5^{\circ} 2 \theta$ peak, was found to be $28 \mathrm{~nm}$ for both samples.

Results show that excess methane relative to the proportion of oxidant implies carbon formation, mostly owed to the cracking of methane (equation 5). As described by Luisetto et al. (2015), large $\mathrm{Ni}$ clusters seem to favor carbon deposition. Hence, the design strategy of the pyrochlore-perovskite clearly prevents carbon formation at relatively low $\mathrm{CH}_{4} / \mathrm{CO}_{2}$ ratio.

XRD of the post-reacted samples are shown in Figure 6. Besides the already described pyrochlore, perovskite and metallic $\mathrm{Ni}$ peaks, a peak corresponding to the graphite lattice plane (002) of carbon nanotubes appears around $26^{\circ} 2 \theta$ (Ferlauto et al., 2006). This peak increases with the $\mathrm{CH}_{4} / \mathrm{CO}_{2}$ ratio, especially on the supported sample, implying a higher carbon deposition with larger amounts of methane in the model biogas, which agrees with the deactivation observed in Figure 4 and the thermodynamic calculations. However, little $\mathrm{Ni}^{0}$ sintering 

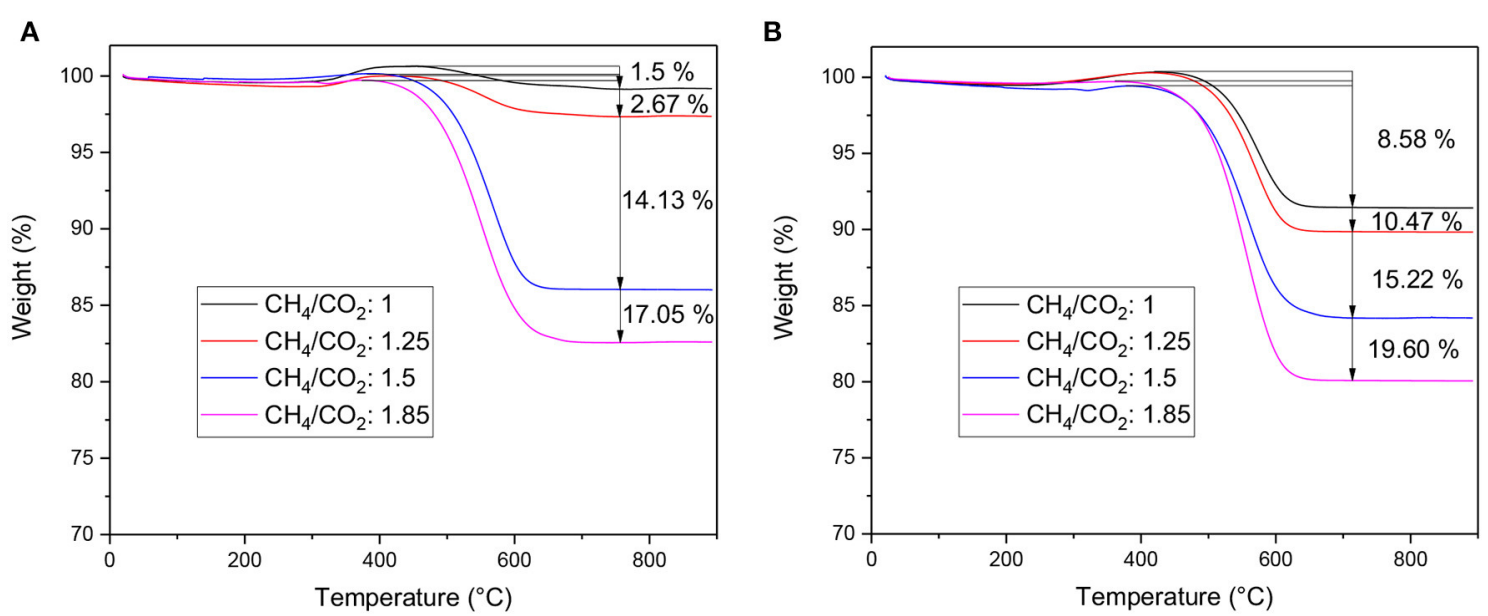

FIGURE 8 | TGA of the samples after stability test. (A) LNZ10 and (B) Ni/LZ.

was evidenced. Scherrer analysis of the peak at $44,4^{\circ} 2 \theta$ shows that the crystallite size varied between 26 and $29 \mathrm{~nm}$ for the doped sample and between 28 and $30 \mathrm{~nm}$ for the supported sample. The initial activity of the doped catalyst may be due to the $\mathrm{Ni}$ particles resulting from the reduction of $\mathrm{LaNiO}_{3}$. Later, the exsolution of $\mathrm{Ni}$ from the mixedperovskite/pyrochlore phases may occur and provide new active sites (le Saché et al., 2018). Indeed, TEM images of the doped sample before and after reacting for $24 \mathrm{~h}$ under a $\mathrm{CH}_{4} / \mathrm{CO}_{2}$ ratio of 1 are shown in Figure 7. No Ni particle were distinguished on the calcined sample as it is integrated in various structures according to the XRD profile. After time dependent reaction, $\mathrm{Ni}$ particles can clearly be distinguished with diameters larger than $10 \mathrm{~nm}$. These particles could result from the exsolution of $\mathrm{Ni}$ from the various phases and their subsequent sintering.

\section{Carbonaceous Deposits Evaluation}

Thermogravimetric analysis was conducted on the samples after reacting for $24 \mathrm{~h}$ to estimate the carbon deposits formed during the reaction. Figure 8 shows the effect of $\mathrm{CH}_{4} / \mathrm{CO}_{2}$ ratio on the feed on coke deposition. A slight weight gain is observed on all samples at $400^{\circ} \mathrm{C}$ corresponding to the oxidation of nickel. Very limited carbon formation was detected on the doped catalyst after reforming of the model mixture and landfill waste produced biogas. This is in good agreement with the catalytic data. The activity stabilized after $15 \mathrm{~h}$ of reaction and showed limited deactivation. Only $15 \mathrm{mg}_{\mathrm{C}} \mathrm{g}_{\text {cat }}^{-1}$ was formed using model biogas whereas for the biogas mixture $2,141 \mathrm{mg}_{\mathrm{C}} \mathrm{g}_{\text {cat }}^{-1}$ was formed. It appears that the doped catalyst is able to resist carbon deposition for $\mathrm{CH}_{4} / \mathrm{CO}_{2}$ mixture up to 1.25 . Beyond this ratio, the catalyst displayed steady deactivation. In comparison, the impregnated catalyst displayed important amount of coke for all tested mixtures. An outstanding amount of coke was formed during the reforming of the model mixture,
$85.8 \mathrm{mg}_{\mathrm{C}} \mathrm{g}_{\text {cat }}^{-1}$, despite the equimolar amount of oxidant. At higher $\mathrm{CH}_{4} / \mathrm{CO}_{2}$ ratios however, the amount of carbon deposits is quite similar between the two catalysts, highlighting the threshold of methane content that the doped catalyst can fully oxidize to $\mathrm{CO}$.

\section{CONCLUSIONS}

Herein we demonstrate the excellent activity of a Ni-substitute pyrochlore catalyst for biogas upgrading to syngas via dryreforming processes. The stabilizing effect of the pyrochlore framework offers a unique environment for $\mathrm{Ni}$ active sites to be protected from severe deactivation resulting in highly dispersed $\mathrm{Ni}$ ensembles. Indeed, after the reaction, small $\mathrm{Ni}$ clusters are present on the surface of the catalyst as suggested by XRD. In fact, it is very likely that active Ni clusters are exsolved from the pyrochlore during DRM leading to highly dispersed Ni clusters which account for the high activity and stability of the catalyst during the reaction. For sake of fair comparison, a standard $\mathrm{Ni}$ supported on a pyrochlore structure was tested under the same conditions. The Ni-substitute pyrochlore systems outperform the behavior of the supported material for all the tested conditions. Especially during the reforming of methane-rich biogas mixtures, the small Ni particles allowed an exceptional carbon resistance in comparison to the reference impregnated catalyst. Beyond the structure robustness of this novel reforming catalysts, this work showcases its applicability to multiple biogas mixtures including surrogates of landfill, sewage, and organic wastes with different $\mathrm{CH}_{4} / \mathrm{CO}_{2}$ ratios. This is a very interesting result indicating that our Ni-doped pyrochlore catalysts is not active for DRM but it also offers flexibility in terms of biogas mixtures. We can actually fine-tune the end-product composition by implementing our catalyst to upgrade multiple biogas mixtures thus resulting in a unique flexible catalyst for bio-syngas production paving toward the way to sustainable chemical synthesis. 


\section{DATA AVAILABILITY STATEMENT}

The raw data supporting the conclusions of this article will be made available by the authors, without undue reservation.

\section{AUTHOR CONTRIBUTIONS}

All authors listed have made a substantial, direct and intellectual contribution to the work, and approved it for publication.

\section{REFERENCES}

Abdulrasheed, A., Jalil, A. A., Gambo, Y., Ibrahim, M., Hambali, H. U., and Shahul Hamid, M. Y. (2019). A review on catalyst development for dry reforming of methane to syngas: recent advances. Renew. Sustain. Energy Rev. 108, 175-193. doi: 10.1016/j.rser.2019.03.054

Aziz, M. A. A., Setiabudi, H. D., Teh, L. P., Annuar, N. H. R., and Jalil, A. A. (2019). A review of heterogeneous catalysts for syngas production via dry reforming. J. Taiwan Inst. Chem. Eng. 101, 139-158. doi: 10.1016/j.jtice.2019.04.047

Chein, R. Y., Chen, Y. C., Yu, C. T., and Chung, J. N. (2015). Thermodynamic analysis of dry reforming of $\mathrm{CH} 4$ with $\mathrm{CO} 2$ at high pressures. J. Nat. Gas Sci. Eng. 26, 617-629. doi: 10.1016/j.jngse.2015.07.001

Dama, S., Ghodke, S. R., Bobade, R., Gurav, H. R., and Chilukuri, S. (2018). Active and durable alkaline earth metal substituted perovskite catalysts for dry reforming of methane. Appl. Catal. B Environ. 224, 146-158. doi: 10.1016/j.apcatb.2017.10.048

Ferlauto, A. S., de Florio, D. Z., Fonseca, F. C., Esposito, V., Muccillo, R., Traversa, E., et al. (2006). Chemical vapor deposition of multi-walled carbon nanotubes from nickel/yttria-stabilized zirconia catalysts. Appl. Phys. A 84, 271-276. doi: 10.1007/s00339-006-3617-x

Haynes, D. J., Shekhawat, D., Berry, D. A., Zondlo, J., Roy, A., and Spivey, J. J. (2017). Characterization of calcination temperature on a Ni-substituted lanthanum-strontium-zirconate pyrochlore. Ceram. Int. 43, 16744-16752. doi: 10.1016/j.ceramint.2017.09.068

Khajonvittayakul, C., Tongnan, V., Kangsadan, T., Laosiripojana, N., Jindasuwan, S., and Hartley, U. W. (2019). Thermodynamic and mechanism study of syngas production via integration of nitrous oxide decomposition and methane partial oxidation in the presence of $10 \% \mathrm{NiO}-\mathrm{La}_{0.3} \mathrm{Sr}_{0.7} \mathrm{Co}_{0.7} \mathrm{Fe}_{0.3} \mathrm{O}_{3-\delta}$. React. Kinet. Mech. Catal. 127, 839-855. doi: 10.1007/s11144-019-01600-1

Lanzini, A., and Leone, P. (2010). Experimental investigation of direct internal reforming of biogas in solid oxide fuel cells. Int. J. Hydrogen Energy 35, 2463-2476. doi: 10.1016/j.ijhydene.2009.12.146

le Saché, E., Pastor-Pérez, L., Garcilaso, V., Watson, D. J., Centeno, M. A., Odriozola, J. A., et al. (2020). Flexible syngas production using a La2Zr2-xNixO7- $\delta$ pyrochlore-double perovskite catalyst: towards a direct route for gas phase CO2 recycling. Catal. Today 357, 583-589. doi: 10.1016/j.cattod.2019.05.039

le Saché, E., Pastor-Pérez, L., Watson, D., Sepúlveda-Escribano, A., and Reina, T. R. (2018). Ni stabilised on inorganic complex structures: superior catalysts for chemical CO2 recycling via dry reforming of methane. Appl. Catal. B Environ. 236, 458-465. doi: 10.1016/j.apcatb.2018.05.051

Luisetto, I., Tuti, S., Battocchio, C., Lo Mastro, S., and Sodo, A. (2015). Ni/CeO2$\mathrm{Al} 2 \mathrm{O} 3$ catalysts for the dry reforming of methane: the effect of $\mathrm{CeAlO} 3$ content and nickel crystallite size on catalytic activity and coke resistance. Appl. Catal. A Gen. 500, 12-22. doi: 10.1016/j.apcata.2015.05.004

Neubauer, Y. (2013). "Biomass gasification," in Biomass Combustion Science, Technology, and Engineering, ed L. Rosendahl (Cambridge: Woodhead Publishing), 106-129.

Pakhare, D., Haynes, D., Shekhawat, D., and Spivey, J. (2012). Role of metal substitution in lanthanum zirconate pyrochlores $\left(\mathrm{La}_{2} \mathrm{Zr}_{2} \mathrm{O}_{7}\right)$ for dry $\left(\mathrm{CO}_{2}\right)$ reforming of methane (DRM). Appl. Petrochem. Res. 2, 27-35. doi: 10.1007/s13203-012-0014-6

Papadopoulou, C., Matralis, H., and Verykios, X. (2012). "Utilization of biogas as a renewable carbon source: dry reforming of methane," in Catalysis for

\section{FUNDING}

Financial support for this work was also provided by the Royal Society Research Grant RSGR1180353. This work was also partially sponsored by the $\mathrm{CO} 2 \mathrm{Chem}$ UK through the EPSRC grant EP/P026435/1, and the Spanish Ministry of Science and Innovation through the project RYC2018-024387-I.

Alternative Energy Generation, eds L. Guczi and A. Erdôhelyi (New York, NY: Springer New York), 57-127.

Perry, R. H., Green, D. W., and Maloney, J. O. (1997). Perry's Chemical Engineers' Handbook. New York, NY: McGraw-Hill.

Reina, T. R., Le Saché, E., Gu, S., Watson, D., Pérez, L. P., and Escribano, A. S. (2020). Catalysts for the Reforming of Gaseous Mixtures. Google Patents.

Ren, J., Liu, Y.-L., Zhao, X.-Y., and Cao, J.-P. (2020). Biomass thermochemical conversion: a review on tar elimination from biomass catalytic gasification. J. Energy Inst. 93, 1083-1098. doi: 10.1016/j.joei. 2019.10.003

Santos, R. G. D., and Alencar, A. C. (2020). Biomass-derived syngas production via gasification process and its catalytic conversion into fuels by Fischer Tropsch synthesis: a review. Int. J. Hydrogen Energy 45, 18114-18132. doi: 10.1016/j.ijhydene.2019.07.133

Shiratori, Y., Ijichi, T., Oshima, T., and Sasaki, K. (2010). Internal reforming SOFC running on biogas. Int. J. Hydrogen Energy 35, 7905-7912. doi: 10.1016/j.ijhydene.2010.05.064

Shukla, R., Vasundhara, K., Krishna, P. S. R., Shinde, A. B., Sali, S. K., Kulkarni, N. K., et al. (2015). High temperature structural and thermal expansion behavior of pyrochlore-type praseodymium zirconate. Int. J. Hydrogen Energy 40, 15672-15678. doi: 10.1016/j.ijhydene. 2015.09.059

Ullah Khan, I., Hafiz Dzarfan Othman, M., Hashim, H., Matsuura, T., Ismail, A. F., Rezaei-DashtArzhandi, M., et al. (2017). Biogas as a renewable energy fuela review of biogas upgrading, utilisation and storage. Energy Convers. Manag. 150, 277-294. doi: 10.1016/j.enconman.2017.08.035

Wu, D., Li, L., Zhao, X., Peng, Y., Yang, P., and Peng, X. (2019). Anaerobic digestion: a review on process monitoring. Renew. Sustain. Energy Rev. 103, 1-12. doi: 10.1016/j.rser.2018.12.039

Zhang, J., Wang, H., and Dalai, A. K. (2007). Development of stable bimetallic catalysts for carbon dioxide reforming of methane. J. Catal. 249, 300-310. doi: 10.1016/j.jcat.2007.05.004

Zhang, X., Fang, X., Feng, X., Li, X., Liu, W., Xu, X., et al. (2017). Ni/Ln2Zr2O7 $(\mathrm{Ln}=\mathrm{La}, \mathrm{Pr}, \mathrm{Sm}$ and $\mathrm{Y}$ ) catalysts for methane steam reforming: the effects of a site replacement. Catal. Sci. Technol. 7, 2729-2743. doi: 10.1039/C7 CY00004A

Zhao, X., Joseph, B., Kuhn, J., and Ozcan, S. (2020). Biogas reforming to syngas: a review. iScience 23:101082. doi: 10.1016/j.isci.2020.101082

Zheng, Y., Li, K., Wang, H., Tian, D., Wang, Y., Zhu, X., et al. (2017). Designed oxygen carriers from macroporous $\mathrm{LaFeO} 3$ supported $\mathrm{CeO} 2$ for chemical-looping reforming of methane. Appl. Catal. B Environ. 202, 51-63. doi: 10.1016/j.apcatb.2016.08.024

Conflict of Interest: The authors declare that the research was conducted in the absence of any commercial or financial relationships that could be construed as a potential conflict of interest.

Copyright (C) 2021 le Saché, Alvarez Moreno and Reina. This is an open-access article distributed under the terms of the Creative Commons Attribution License (CC BY). The use, distribution or reproduction in other forums is permitted, provided the original author(s) and the copyright owner(s) are credited and that the original publication in this journal is cited, in accordance with accepted academic practice. No use, distribution or reproduction is permitted which does not comply with these terms. 